\title{
Turkish Primary Science Teacher Candidates' Understandings of Global Warming and Ozone Layer Depletion*
}

\author{
Fatma Aggul Yalcin ${ }^{1}$, Mehmet Yalcin ${ }^{1}$ \\ ${ }^{1}$ Agri Ibrahim Cecen University Education Faculty, Agri, Turkey \\ Correspondence: Fatma Aggul Yalcin, Agri Ibrahim Cecen University Education Faculty, 04000, Agri, Turkey.
}

Received: February 15, 2017

Accepted: March 26, 2017

Online Published: September 25, 2017

doi:10.11114/jets.v5i10.2225

URL: https://doi.org/10.11114/jets.v5i10.2225

\begin{abstract}
The purpose of the study was to explore Turkish primary science teacher candidates' understanding of global warming and ozone layer depletion. In the study, as the research approach the survey method was used. The sample consisted of one hundred eighty nine third grade science teacher candidates. Data was collected using the tool developed by the researcher. The survey solicited written opinion responses to seven open-ended questions. Teacher candidates' written opinions about global warming and ozone layer depletion were analyzed descriptively. The results of the analysis were presented as percentages and frequency. The findings suggest that prospective teachers' understandings about these issues were limited and they had some significant common, misconceptions. Finally, the findings were discussed in comparison with the previous research with respect to environmental education.
\end{abstract}

Keywords: global warming, ozone layer depletion, environmental education, primary science teacher training

\section{Introduction}

The studies related to global warming show that carbon dioxide $\left(\mathrm{CO}_{2}\right)$ and other greenhouse gases have markedly changed the chemical composition of the world's atmosphere in comparison with the 100-150 years ago (Flavin, 1990; Bahar and Aydin, 2002). Among greenhouse gases, $\mathrm{CO}_{2}$ has a unique place and importance. The amount of carbon dioxide in the atmosphere, mainly a result of the use of fossil fuels, has been increasing rapidly. However, deforestation, in particular the destruction of tropical rain forests, as well as new vegetation in forest areas in other parts of world, has contributed to this increase (Ozturk, 2002; Cepel, 2008; Kahraman et al. 2008). With global warming leading to climate change, it is expected that serious environmental problems, such as massive flooding resulting from melting polar ice caps, elevation in sea levels, the increase in evaporation in some aquatic areas, and drought are likely to increase (Greenpeace, 1990; Bockis et al. 2002).

Another important environmental problem facing the world is the depletion of the ozone layer. Scientific research reveals that, by a consecutive chemical reaction, the ozone layer filters the sun's ultraviolet rays, which contain $90 \%$ of the sun's harmful rays, shielding organisms from their harmful effects (Onat, Imal and Inan, 2004; Topsakal and Kara, 2009). The thinning of ozone layer as a result of human activities has caused further ultraviolet (UV) radiation from the sun to reach earth and endanger mankind and other biological life (Cordero, 2000). It has long been known that chemicals, like Chlorofluorocarbons (CFCs), damage the ozone layer. It is estimated that a $1 \%$ increase in these chemicals leads to a $2 \%$ increase in the harmful rays reaching the world. Thinning of the ozone layer and climate change leads to adverse consequences such as the weakening of the immune system, skin cancer and cataracts disease (Diffey, 2000; Cinar, 2003; Onat, Imal and Inan, 2004; Akın, 2008; Topsakal and Kara, 2009).

In the prevention of the thinning of the ozone layer and global warming, public awareness is important. Education in schools is among the most important means of increasing this awareness. In science courses, these issues are of great importance to be addressed. Already, in primary and secondary education, science- technology-society course outcomes should be evaluated from this perspective. This, however, can be achieved thanks to teachers with high awareness, with knowledge of these issues. Therefore, to determine the prospective teachers' understanding of these issues will provide valuable information for researchers and educators.

*This study was partly presented in 1st International Turkic World Conference on Chemical Sciences and Technologies, 27 October and 01 November 2015 in Bosnia and Herzegovina (Sarajevo). 


\subsection{Literature Review}

In the literature there have been a number of studies about students' and teachers' understanding of global warming and the thinning of the ozone layer (Boyes and Stanisstreet,1993; Boyes, Chambers and Stanisstreet, 1995; Dove, 1996; Rye et al. 1997; Koulidis and Christidou, 1999; Meadows and Wiesenmayer, 1999; Groves and Pugh,1999; Cordero, 2000; Bozkurt and Cansungu Koray, 2002; Bahar and Aydin, 2002; Spellman, Field and Sinclair, 2003; Khalid, 2003; Bozkurt and Aydogdu, 2004; Papadimitriou, 2004; Pekel and Ozay, 2005; Darcin, Bozkurt, Hamalosmanoglu and Kose, 2006; Daskolia et al. ,2006; Pekel, Kaya and Demir, 2007; Cepel and Ergun, 2007; Kahraman et al. 2008; Bozkurt And Kaya, 2008; Bahar, Bag, and Bozkurt, 2008; Kaya, 2009; Topsakal and Kara, 2009; Jakobsson, Makitalo, and Saljo 2009; Shepardson et al. 2009; Arsal, 2010, Aydın, 2010; Bozdogan and Yanar, 2010; Cakir, Irez and Dogan, 2010; Bozdogan, Karslı and Sahin, 2011; Çelikler and Kara, 2011). Previous studies have shown that students confuse distinct environmental problems and students at various levels of education had some misconceptions such as "global warming results from the thinning of the ozone layer", (Boyes et al. 1995; Dove, 1996; Rye, Rubba and Wiesenmayer, 1997; Papadimitriou, 2004; Pekel and Ozay, 2005; Darcin et al. 2006) and "the reason for the depletion of the ozone layer is global warming," (Boyes and Chambers, 1995; Rye, 1997; Boyes et al. 1999; Pekel and Ozay, 2005; Selvi, 2007; Bozdogan and Yanar, 2010, Topsakal and Kara, 2009). Furthermore, the studies emphasized that students lack sufficient knowledge about the effects of global warming and ozone depletion (Dove, 1996; Bahar, 2000; Bahar and Aydin, 2002).

Shepardson et al. (2009) investigated seventh grade students' conceptions of global warming and climate change. They reported that the students' conceptions of global warming and climate change were similar to the results of previous studies, in that the pupils lacked a rich conceptualization of the issue, especially as they pertain to the greenhouse effect and its connection to global warming. Rye et al. (1997) explored the varying conceptions of global warming held by grade 6-8 students. Results indicated that approximately one-half of the students held the view that ozone layer depletion is a major cause of global warming and that carbon dioxide destroys the ozone layer. They argued that global warming instruction should help students distinguish ozone layer depletion from global warming, and understand that the ozone 'hole' does enhance the greenhouse effect.

Another study conducted by Koulidis and Christidou (1999) evaluated primary school (aged 11-12) students' conceptions of the greenhouse effect. They found that children believed that the greenhouse effect is due to solar radiation that heats up the earth and the atmosphere. That radiation is trapped by certain atmospheric gases, which severely changes the climate, melts the polar icecaps, and raises the sea level. Hansen (2010) examined the development of pupils' knowledge about the greenhouse effect and the effects of the ozone layer from 1989 to 2005 in Norway. He argued that there is an increase in the number of pupils that confuse the greenhouse effect with the effects of the ozone layer in comparison with previous years. Cakir et al. (2010) also examined future science teachers' understandings of biodiversity, carbon cycle, global warming and ozone layer depletion. Findings showed that students had the following misunderstandings:

Pollution from burning fossil fuels, e.g. from car engines, is destroying the ozone layer.

Car engines and Industrial processes in factories emit lots of ozone directly into the air.

Holes in the ozone layer will never be repaired naturally.

Ozone is a pollutant which thins the atmosphere to let more ultra-violet light through.

Man-made pollution traps heat entering through holes in the ozone layer to cause global warming.

Global warming is caused by the ozone layer trapping the extra heat entering through its holes.

Global warming is caused by a layer of high altitude $\mathrm{CO}_{2}$.

Man cutting down forests has no effect on the amount of carbon dioxide present in the Earth's atmosphere.

Since global warming may be a natural effect there is no need to take precautions against it.

Boyes and Stanisstreet, (1993) conducted a study with 11 and 16-years-olds in the UK. He reported that students hold the view that events of food poisoning in humans would be more frequent as a result of global warming and that glaciers, due to global warming, would melt and thus flood incidents would occur. In a previous study conducted with university students by Boyes et al. (1995), he found that while the vast majority of students think that the ozone layer is a gas layer protecting the world from harmful UV rays and occurring naturally, a significant portion of the students saw environmental pollutants as the reason for the depletion of the ozone layer, and, authors emphasized that they are not aware of the damage to the ozone layer of volcanic eruptions, and believed that ozone layer depletion increased the greenhouse effect. In another study conducted with teacher candidates, Dove (1996) referred to teacher candidates exhibiting the same misconception: "the greenhouse effect is a result of ozone layer depletion". In an investigation 
conducted by Andersson and Wallin (2000) on fifth, ninth, and twelfth-grades, it was found that students lacked a sound and clear understanding of the effects of reduced $\mathrm{CO}_{2}$ emissions on the environment, though they exhibited understanding of negative impact of $\mathrm{CO}_{2}$ on the ozone layer and consequent risks for people.

Cordero (2000) established that Australian students believed that a large part of the ozone layer was over Australia and the high rate of skin cancer in Australia is mainly due to thinning of the ozone layer. Bahar and Aydin (2002) examined pre-service primary teachers' knowledge about greenhouse gases and global warming. They showed that teacher candidates' knowledge of the concepts is inadequate and occasionally erroneous. Three-fourths of them understood the greenhouse effect as an issue related to agriculture. Bozkurt and Aydogdu (2004) also studied 6th, 7th, and 8th grade primary students' conceptions of the ozone layer and its functions. Misconceptions were like: the "function of the ozone layer is to protect the earth against high temperature", "in the case of ozone depletion the earth could be exposed to high harmful temperatures," and "as a result of the fires smoke and gases emitted from car exhausts and factories, ozone layer is thinning".

The findings from Pekel and Ozay (2005) demonstrated that although the majority of high school students had good knowledge about the ozone layer, they carried some misconceptions concerning the causes and consequences of ozone depletion and they argued that few students had knowledge about the effects of UV radiation. The authors argued that the same students held the opinion that the depletion of the ozone layer would increase global warming and thus floods, heart attacks, extinction of aquatic organisms, changes in water resources would occur. In a study of 6th, 7th and 8th grade students' level of knowledge about the greenhouse effect, Darcin et al. (2006), wrote that students' knowledge level was very low and showed paralelism among grades. The study reported some of the following misconceptions: If the greenhouse effect increases, more people will catch skin cancer, and thinning of the ozone layer would further increase the greenhouse effect. Findings of Demirkaya (2008) also drew attention to students' confusion between global warming and ozone layer depletion. The teacher candidates in this study thought that global warming was an expansion of the hole in the ozone layer over time.

Arsal (2010) showed that prospective primary teachers think that more sun rays reaching earth would strengthen the greenhouse gas effect, that acid rain and hormone usage in agriculture would increase its impact, and thus would appear vast fish deaths in the sea, lakes and rivers and increasing number of earthquakes. In a similar study, Topsakal and Kara (2009) revealed some invalid understandings such as that "ozone protects the world against acid rain", "emissions from cars damage the ozone layer", "one of the causes of ozone thinning is the greenhouse effect", "holes in the ozone layer would result in more heat reaching the earth, and "the amount of glacier melting in the poles depends on thinning in the ozone layer". Again, findings from the research done by Spellman, Field and Sinclair (2003) showed that there are significant differences with respect to understandings of the greenhouse effect and ozone layer depletion both between students for whom books are a source of information and those for whom TV is a source, and between-non science and science students. However, there was not found any differences according to gender and age variables, suggesting that TV and schooling have a strong effect on students' perceptions of the concepts.

Cakir, Irez and Dogan (2010) indicated that prospective teachers had some significant misconceptions of global warming and ozone layer depletion. The some misconceptions identified in the study are the following.

Holes in the ozone layer let too much heat from the Sun get through to Earth

Holes in the ozone layer will never be repaired naturally.

Man-made pollution traps heat entering through holes in the ozone layer to cause global warming.

Trapping the extra heat entering through its holes, the ozone layer causes global warming...

\subsection{Problem of Research}

The purpose of the study was to explore primary science teacher candidates' understanding of global warming and ozone layer depletion. It is believed, aiming to determine pre-service primary science teachers' understanding and level of awareness of the important environmental problems of our age, this study will provide an important contribution to establishing effective environmental education and teacher training.

\section{Methodology of Research}

In this study, the survey method was used. This approach is one method used often to determine human attitudes, beliefs, values, habits and thoughts about various issues (McMillian and Schumacher, 2004, p. 304).

\subsection{Sample of Research}

The sample of the study, a convenience sample, was consisted of one hundred eighty nine primary science teacher candidates, aged 18-24, enrolled in Department of Primary Education in a State University in Turkey. 


\subsection{Instrument and Procedures}

The study aimed to determine primary science teachers' understandings of global warming and the thinning of ozone layer by analyzing written answers to seven open-ended questions developed by the researchers. The scale's validity was established by field and language experts, and necessary changes, according to the suggestions of the experts, were made. Then, it was implemented to one hundred eighty nine science teacher candidates. It was observed teacher candidates responded watchfully the questions. The questions were given below:

- Can you explain global warming process and which substances are the causes of global warming?

- What are the possible effects of global warming upon the environment and people?

- What action should the state government take to prevent global warming?

- What actions should individuals take to prevent global warming?

- What is the reason for the ozone layer's depletion and what could be its effects?

- What is the function of the ozone layer for the planet?

- Is there any relationship between the factors that lead to depletion of the ozone layer and those that lead to global warming?

\subsection{Data Analysis}

The teacher candidates' responses to the written questions were subjected to descriptive analysis. Before the analysis, some pre-determined codes to categorize written opinions were developed in light of the research questions. Written opinions were individually analyzed and categorized by the researcher and one other field expert. It was found that their findings showed the convergence of $87 \%$. During the analysis, the similar views were grouped under the same codes.

\section{Results of Research}

In this section, the findings from the analysis of the teacher candidates' responses to questions are presented in the tables below. For the first question "What is global warming and what are the substances that cause global warming?" The findings are given in Table 1 and 2.

Table 1. The teacher candidates' opinions of global warming

\begin{tabular}{lll}
\hline \multicolumn{1}{c}{ Opinions } & $\mathrm{f}$ & $\%$ \\
\hline Climate change & 51 & 27,0 \\
Narrowing of the ozone layer due to rays emitted from the sun & 21 & 11,1 \\
The deterioration of the natural balance & 27 & 14,3 \\
Increase in the temperature & 42 & 22,2 \\
Prevention of light from reflecting back into space by greenhouse gases & 27 & 14,3 \\
No response & 21 & 11,1 \\
\hline
\end{tabular}

As can been in Table 1, while respectively, 27.0 and 22.2 percent of teacher candidates' view global warming as climate change and temperature increase, which indeed are the effects of global warming, other $14.3 \%$ of them define as a deterioration of the natural balance which imply they understand superficially this concept. A minority (11.1\%) of teacher candidates thought that the thinning of the ozone layer, due to rays coming from the sun, was global warming. But, another $14.3 \%$ gave an acceptable explanation that global warming occurs when greenhouse gases block the rays from the earth deterring reflecting back into space. Some excerpts from the responses to the first question are given below.

Global warming is a temperature increase as a result of the accumulation of gases such as $\mathrm{CFCs}, \mathrm{CO}_{2}$, and $\mathrm{CH}_{4}$ in the atmosphere.

Global warming is the change of climates as a consequence of the sun's rays falling directly to earth due to the thinning of the ozone layer.

Global warming is not an increase in the world's temperature, but the change of climates.

Due to the increasing atmospheric density of gases such as $\mathrm{CO}_{2}$ and $\mathrm{CH}_{4}$ in the atmosphere, the deterioration of the natural balance and the increase of temperature are called global warming.

Global warming is a disruption of the natural equilibrium owing to industry and technology activities and the change of the seasons.

Global warming is the arrival of harmful rays to earth and temperature rise, on account of ozone depletion resulting from chemical pollution. 
Table 2. Teacher candidates' opinions of the agents causing global warming the agents causing global warming

\begin{tabular}{lll}
\hline & $\mathrm{f}$ & $\%$ \\
\hline $\mathrm{CO}_{2}, \mathrm{CH}_{4}, \mathrm{CFC}, \mathrm{H}_{2} \mathrm{O}$ & 87 & 46,0 \\
Cosmetics products, such as perfumes, deodorant & 39 & 20,6 \\
Funnel and automobile exhaust gases & 45 & 23,8 \\
Thinning of the ozone layer & 18 & 9,5
\end{tabular}

In Table 2, Teacher candidates' perceptions about global warming agents showed that the vast majority (46.0\%) of the candidates hold the sound understanding that the rising atmospheric percentages of compounds, such as $\mathrm{CO}_{2}, \mathrm{CH}_{4}$, CFCs, and $\mathrm{H}_{2} \mathrm{O}$. Regarding the main agent of global warming, while $23.8 \%$ of candidates cited Funnel gases released by factories and companies in various industries, automobile exhaust gases and motor vehicles exhaust gases, $20.6 \%$ cited increasing consumption of cosmetic products such as perfume and deodorant. 9.5\% of responses reflected the misconception that "the cause of global warming is the thinning ozone layer." The following excerpts support these findings.

Unconscious use of perfumes sprays.

Toxic gases emitted from industrial companies and factories.

People and technological tools.

Rays from the sun directly reach to the earth because of ozone layer depletion increasing atmospheric density of chemicals, such as $\mathrm{CO}_{2}, \mathrm{CH}_{4}, \mathrm{CFCs}$, water vapor.

Toxic gases from automobile exhausts.

Table 3. Teacher candidates' opinions of the effects of global warming on nature and people

\begin{tabular}{lll}
\hline \multicolumn{1}{c}{ Opinions } & $\mathrm{f}$ & $\%$ \\
\hline Melting of glaciers, climate change, some species extinct & 93 & 49,2 \\
Drought and desertification & 48 & 25,4 \\
$\begin{array}{l}\text { Increased acid rain, the emergence of some health problems and deadly } \\
\text { diseases }\end{array}$ & 39 & 20,6 \\
Thinning of the ozone layer & 9 & 4,7 \\
\hline
\end{tabular}

As detailed in table 3, 49.2\% of teacher candidates' associated global warming with climate change and said that melting glaciers would lead to some species' extinction. $25.4 \%$ of them exhibited the understanding that, because of global warming, droughts and desertification would increase. The view that global warming will cause acid rain, and thus cause health problems and deadly diseases in people consuming products from agricultural land by affected acid-rains was held by $20.6 \%$ of candidates. The finding is reflected in the following excerpts from written comments.

With the disruption of natural balance, incidence of people acquiring various diseases of people increases.

Climate change occurs and some species would be adversely affected by this situation and some species would become extinct.

Water problems emerge, and drought begins.

The rate of skin cancer increased.

Acid rain and soil structure deteriorates and fatal diseases in humans fed with products grown on these lands would appear.

Land would be covered with water with the melting of glaciers and, thus the natural balance is disrupted.

The seasons would change; dry places would get plenty of rainfall, while in lands where water is abundant drought would be seen. 
Table 4. Teacher candidates' opinions of the state-level responsibilities to prevent global warming

\begin{tabular}{lll}
\hline \multicolumn{1}{c}{ Opinions } & $\mathrm{f}$ & $\%$ \\
\hline Public awareness & 63 & 33,3 \\
Taking measures to reduce harmful gas emissions of factories and industrial & 48 & 25,4 \\
establishments and to control often & 24 & 12,7 \\
Limiting the sale of cosmetic products, such as perfume, deodorant & 21 & 11,1 \\
To forestation & 15 & 8,0 \\
Curbing fossil fuel consumption & & \\
\hline
\end{tabular}

From Table 4, it can be seen that $33.3 \%$ of teacher candidates think that to prevent global warming the state should make people and industry organizations conscious of the effects of global warming and draw attention to this issue with activities such as banners and posters aimed at young people. $25.4 \%$ of them advocated that countries should take measures necessary to cut and control harmful gases emitted by factories and industrial establishments. Moreover, total $23.8 \%$ think that restricting the sale of cosmetic products and forestation and forest conservation should be given more importance. The excerpts from written documents supporting the findings are the following.

Governments should specify the measures to be taken and inform people about global warming.

Governments should provide safe destruction of waste from factories in Industrial zones and guarantee the release of gases from factory chimneys after filtration.

Governments should ban Production, consumption and sale of ozone-damaging substances.

Governments should re-forest and should give more importance to protecting forests.

Governments should inform factories and other institutions and organizations, particularly citizens, about it and put into effect necessary impositions and dissuasive penalties in case of violations.

Governments should inform society through banners and posters and the activities to inform the youth in the target topics.

Governments should join the KYOTO protocol.

Table 5. Teacher candidates' opinions of individual citizen responsibilities to prevent global warming

\begin{tabular}{lll}
\hline \multicolumn{1}{c}{ Opinions } & $\mathrm{f}$ & $\%$ \\
\hline Restricting use of cosmetic products, such as perfume, deodorant & 48 & 25,4 \\
Using more frequently public transport & 24 & 12,7 \\
Water-saving & 18 & 9,5 \\
Use of quality fuel & 15 & 8,0 \\
Efficient use of energy resources & 12 & 6,3 \\
Not using ozone-damaging agents & 12 & 6,3 \\
Forestation & 9 & 4,8
\end{tabular}

Teacher candidates' views on individual responsibilities in preventing global warming revealed that they hold the idea that cosmetic products such as deodorant, perfume should never be used. This idea was shared by nearly one-fourth (25.4\%) of teacher candidates, which is a rather common misconception. This misunderstanding was followed by the opinion that public transport should be preferred. They believed that gases from motor vehicles, i.e. the exhaust gases, result in global warming, so if effective public transportation could be provided, there would be a remarkable reduction in gas emissions, as can be seen in the following excerpts

The use of all kinds of substances of giving $\mathrm{CO}_{2}$ into the atmosphere should be curbed and public transport should be preferred.

Fuels harmless to the environment should be used.

Filter systems should be installed in car exhaust systems and environmentally friendly fuels should be used.

Electricity and water should be used consciously.

People should use cosmetics as little as possible. 
Table 6. Teacher candidates' opinions of cause of thinning of ozone layer

\begin{tabular}{lll}
\hline \multicolumn{1}{c}{ Opinions } & $\mathrm{f}$ & $\%$ \\
\hline Cosmetic products, such as perfume, deodorant & 60 & 31,7 \\
Harmful toxic gases, such as CFC & 60 & 31,7 \\
Greenhouse effect & 27 & 14,3 \\
Chemical pollution, factories and industrial establishments & 24 & 12,7 \\
Increase in the amount of $\mathrm{CO}_{2}$ and fossil fuels & 18 & 9,5 \\
\hline
\end{tabular}

It is obvious from Table 6 that, exhibiting a sound understanding, 31.7\% of teacher candidates thought the gases emitted from cosmetic products such as perfume and deodorant, deplete the ozone layer and another $31.7 \%$ argued harmful toxic-gases released to the atmosphere, such as ozone-depleting CFCs, damage the ozone layer. But, for approximately $14.3 \%$ of teacher candidates, the cause of the thinning of the ozone layer was the greenhouse effect, which is a common misconception. The following quotations from teacher candidates reflect this conception.

Owing to greenhouse gases, thinning in ozone layer occurs.

Ozone layer is depleted due to its reaction with harmful gases.

Ozone layer thins because of toxic gases released from factories.

Ozone layer thins due to the influence of chemical products such as Perfume, deodorant,

The cause of ozone layer depletion is sprays, air conditioners and CFC released by refrigerators.

Greenhouse gases Creates a layer in the atmosphere. It leads to thinning of ozone layer reflecting back rays from the sun.

Table 7. Teacher candidates' opinions of impacts of thinning of ozone layer on the world

\begin{tabular}{lll}
\hline \multicolumn{1}{c}{ Opinions } & $\mathrm{f}$ & $\%$ \\
\hline Increase in the temperature & 30 & 15,8 \\
Arrival of the sun rays to world without filtration & 54 & 28,5 \\
Climate changes & 24 & 12,7 \\
& & 12,7 \\
Increased skin cancer and other cancer types & 24 & 11,1 \\
Global warming & 21 & 11,1 \\
Disrupted natural balance & 21 & 9,5 \\
Increased diseases & 18 &
\end{tabular}

More than one-fourth (28.5\%) of teacher candidates viewed the ozone layer as a filter. In other words, they thought that when the ozone layer thins, the filter is disrupted, and the sun's rays reach the earth's surface directly. Teacher candidates claimed that increase in the world's temperature was a main consequence of ozone depletion (by $15.8 \%$ of them), of the climate changes for $12.7 \%$, and of global warming for $11.1 \%$. The ideas were followed by beliefs such as an increase in cancer, particularly in skin cancer, disrupted natural balance and increased disease acquisition, as exemplified by the following student excerpts:

Heat released as a result of chemical reactions taking place in the ozone layer result in temperature increases and this even leads to global warming.

The harmful rays from the sun directly reach the earth.

When rays harmful to human health such as ultraviolet rays contact directly with living Beings, skin diseases, like skin cancer appear.

Table 8. Teacher candidates' opinions of the function of the ozone layer for the planet

\begin{tabular}{lll}
\hline \multicolumn{1}{c}{ Opinions } & $\mathrm{f}$ & $\%$ \\
\hline It shield harmful rays, such as UV rays from the sun & 159 & 84.1 \\
It sustain life in the earth & 24 & 12,7 \\
It hold the temperature of the world constant & 6 & 3,1 \\
\hline
\end{tabular}


It is apparent from Table 8 that $84,1 \%$ of students had the opinion that "the ozone layer shields harmful rays such as UV rays from the sun" regarding the role it plays for the world. And finally, $12.7 \%$ and $3.1 \%$ pointed out its importance for life on our planet and in sustaining temperate temperature on earth, respectively. Below are given the excerpts illustrating the findings.

It protects the world against possible harm, for example UV rays, coming from space, and thus it is essential for sustaining life.

It prevents harmful rays from the sun reaching directly to the earth.

The ozone layer is a layer inhibiting the sun's UV rays from directly to coming to our planet.

Table 9. Teacher candidates' opinions whether there is relationship between the factors leading to depletion of the ozone layer and those of global warming?

\begin{tabular}{lll}
\hline \multicolumn{1}{c}{ Opinions } & $\mathrm{f}$ & $\%$ \\
\hline Ozone layer depletion causes global warming & 78 & 41,3 \\
Thinning of the ozone layer is dependent on the same the cause as global warming; & 57 & 30,1 \\
human activities & 24 & 12,7 \\
The greenhouse effect causes the thinning ozone layer & 30 & 15,8 \\
No response &
\end{tabular}

It is clear from the above table that $30.1 \%$ of teacher candidates stated that causes of both the thinning of ozone layer and global warming are shared and it is anthropogenic problem. While a near-majority of them (41.3\%) saw the thinning of the ozone layer as the reason for global warming, the percentage of students claiming that "global warming causes the ozone layer's thinning is $12.7 \%$. These ideas are also supported by the following excerpts.

Between the factors inducing ozone layer depletion and global warming, there is a relationship.

Global warming increases with increasing thinning of the ozone layer. Because the accumulated gases exert a pressure on the ozone layer at a certain point, a thinning of the ozone occurs.

When the ozone layer is thinning, harmful rays from the sun penetrating the earth lead to more heating of earth

As a result of ozone layer depletion global, warming occurs. Gases released into the air while the Carbon containing gases released into the air contain $\mathrm{O}_{3}$ and impair its chemical structure the use of chemical substances makes the ozone layer thin, this influence results in increasing intensity of sunlight reaching the earth, thus an increase in average temperature, that is called global warming.

The reasons for Ozone layer depletion and global warming are similar. As with the global warming effect, ozone layer depletion is a result of toxic gases accumulated in air, and the cause of ozone layer depletion is air pollution. As a result, global warming

occurs.

\section{Discussion and Conclusion}

This study aimed to determine primary science teacher candidates' understanding of global warming and ozone depletion as environmental problems of increasing importance. Findings of the study demonstrated that they lack understanding of these issues and held some important misconceptions.

It was identified that the teacher candidates perceived global warming as climate change and temperature increases, and also confused the effects of global warming with its causes. Similar results have also been demonstrated in the studies by Ozturk (2002), Bozkurt and Aydogdu (2004), Pekel and Ozay (2005), Darcin et al. (2006), Demirkaya (2008) and Kahraman et al. (2008). In this study, a low rate of teacher candidates held the misconception that "global warming is thinning of the ozone layer" a result present in the literature. The study by Rye et al. (1997) showed similar results. Also in the study conducted by Demirkaya (2008) showed that the understanding of global warming as a deterioration of the natural balance was revealed. On the other hand a relatively small proportion of those surveyed (14.3\%) exhibited a sound understanding of global warming.

The teacher candidates' views that gases, such as $\mathrm{CO}_{2}, \mathrm{CH}_{4}, \mathrm{H}_{2} \mathrm{O}$, and CFCs, the so-called greenhouse gases cause global warming implied that they had acceptable conceptual understanding of this issue. In addition, Rye et al. (1997) and Papadimitriou (2004) also demonstrated the conceptual confusion that the cause of global warming is the thinning of ozone layer, which was also found in the current study. The notion that the impact of global warming includes the melting of glaciers, climate change and extinction of some species, health problems and the emergence of deadly 
diseases were reported in studies by Boyes et al. (1993), Darcin et al. (2006), Kahraman et al. (2008), Orbay, Arzu and Melek (2009), Aydin (2010) and Arsal (2010, Bozdoğan and Yanar (2010). As seen in previous studies, the misconception that, global warming will cause the thinning of the ozone layer (Kahraman et al. 2008; Bozdogan and Yanar, 2010) and increased skin cancer (Darcin et al. 2006; Bozdogan and Yanar, 2010) were observed in low percentages in the current study.

They proposed that in preventing global warming, it is necessary for the state to inform people through educational activities, such as seminars about the effects of global warming, banners, and posters. Actions should also include the monitoring of factories that release harmful gases into the atmosphere. They suggested also that the government should place more importance on the planting of green areas and forestation. Kahraman et al. (2008) and Arsal (2010) reported similar results. Similar to the studies of Bozkurt and Cansungu Koray (2002) and Darcin et al. (2006) this study, in contemplating the prevention of global warming, teacher candidates count limitation of the use of CFCs releasing substances beside perfume and deodorant as one of the leading actions individuals should take. The candidate teachers thought that public transport should be preferred to reduce amount of $\mathrm{CO}_{2}$ released from motor vehicles. Similar results were seen in previous studies (Bozkurt and Cansungu Koray (2002), Orbay, Arzu and Melek (2009) and Arsal (2010). Finally, among other findings is the students' idea that reduced water consumption would be effective in preventing global warming.

The teacher candidates noted harmful gases released from products, such as perfume and deodorant and poisonous gases, such as CFCs, as the most important cause of thinning of the ozone layer. This implies teacher candidates had acceptable scientific understandings of the issue. In a previous study, Selvi (2007) reported that teacher candidates viewed CFCs as the cause of the destruction of the ozone layer. The findings of Topsakal and Kara (2009) support the results of the present study, as does most research in the literature (Boyes et al., 1999; Groves and Pugh, 2002; Spellman et al., 2003; Pekel and Ozay, 2005; Pekel, 2005). In the current study, the misconception that thinning of the ozone layer is due to greenhouse effect was not present in a very high proportion. It was shared by just $14.3 \%$ of teacher candidates. However, in the study by Selvi (2007), the misconception was reported at a much higher proportion (82.3\%)

According to the teacher candidates, the unfiltered harmful sun's rays coming into the world are a consequence of ozone layer depletion. This suggests that teacher candidates were aware of the fact that the ozone layer serves as a filter and they think that the thinning occurring in the layer results in more UV rays reaching earth. The study conducted by Pekel and Ozay (2005) encountered similar findings. It was also determined that teacher candidates in the present- study had the misconception that the "thinning of the ozone layer will increase the temperature" (Boyes and Stanisstreet, 1997, Summers et al. 2001; Selvi, 2007) and the "thinning of ozone layer will cause global warming" (Papadimitriou, 2004) reported in the literature. Similarly, Pekel and Ozay (2005), claimed, in their study, that most students (47\%) hold the opinion that the depletion of the ozone layer will lead to the greenhouse effect. In addition, this study and others (Boyes et al. 1995; Pekel and Ozay, 2005; Selvi, 2007; Topsakal and Kara, 2009) underlined how students related increase in cancer incidents, such as skin cancer with the thinning of the ozone layer.

The teacher candidates' understanding that the ozone layer filters harmful rays from the sun and prevents UV rays from reaching the world, and is thus important for the world, suggests that they had the acceptable knowledge of this issue. As similar to findings in the present study, the studies conducted at various grades by Boyes et al. (1995), Boyes et al. (1999), Pekel and Ozay (2005), Pekel et al. 2007, Selvi (2007) and Topsakal and Kara (2009) support this thought; that is, the view that " the ozone layer is important because it protects the planet from UV rays".

In this study the misconception that "the cause of global warming is depletion of the ozone layer" was similar to those found in other studies (Boyes et al. 1995; Dove, 1996; Rye, 1997; Papadimitriou, 2004; Pekel and Ozay, 2005; Darcin et al. 2006). In addition, the opposite view "global warming leads to the thinning of the ozone layer" was also reported in previous studies (Boyes and Chambers, 1995; Rye et al. 1997; Boyes et al. 1999; Pekel and Ozay, 2005; Selvi, 2007; Topsakal and Kara, 2009; Bozdogan and Yanar, 2010). However, though approximately one-third of prospective teachers made a distinction between these two environmental problems, they gave no detailed explanations with respect to their reasons.

Because the members of society most likely to be affected from growing environmental problems are children and young people, it is recommended that environmental education should be given from pre-school period through specific training programs (Yucel and Morgil, 1998; Darcin and Darcin, 2009; Aydin, 2010). According to National Science Education Standards (NSES), the elementary school students should be aware of various natural phenomena. Therefore, teachers have responsibility to overcome related misconceptions and make these facts comprehensible to students in the classroom (Khalid, 2001). Development of environmental awareness in children could be achieved by constructing a scientific conceptual understanding and correcting them after identifying existing misconceptions.

The studies reviewed on global warming and the ozone layer pointed out the lack of knowledge and misconceptions of 
students involved in various levels and fields. To overcome environmental problems such as global warming and the thinning of the ozone layer, besides political solutions and measures, it is necessary to raise public and individual awareness of these issues, and also provide individuals the education of environmental problems in schools (Bozkurt and Aydogdu, 2004).

It is seen obviously that this study's findings have parallels with those in the literature. The findings support the claim that the results from a survey of elementary teachers are comparable to those of students at different education levels. This similarity implies low awareness level and misconceptions of environmental problems beginning at primary school years and lasting into older ages, (Boyes et al. 1995; Pekel, 2005; Pekel et al. 2007). Teachers included in the study have not taken a course directly related to environmental issues in their previous education. But this situation is not enough to explain why they carry their misconceptions and low awareness level of these problems into their twenties. In overcoming environmental problems, such as global warming and the thinning of ozone layer, aside from political solutions, it should be developed individuals' sensitivity and education about these issues. At this point, it is particularly crucial to develop environmental awareness in children, and identify and correct misconceptions related to environmental problems. Additionally, raising individuals' sensitivity to potential political solutions at the governmental level and various legal imperatives is of great importance. It is proposed that to develop individuals' environmental literacy, particularly at primary school level, the appropriate educational programs should be presented. Considering that one of the reasons for students' misconceptions could be that their teachers' do not discuss these issues in the classroom, results suggest that it must be compulsory, during teachers training programs, to include activities to prevent the development of misconceptions of environmental problems and to eliminate existing ones. In this context, in the training process of teacher candidates, it could be beneficial to use materials, such as a documentary about global warming and the thinning ozone layer, photos, posters with the support of visual materials and also environmental excursions, organization of seminars, discussions to get teacher candidates' first-hand knowledge. There are some studies that address effective teaching of environmental problem. For example, in a study conducted by Oluk and Ozalp (2007), the results indicated the effectiveness of concept cartoons in teaching about global environmental problems according to the constructivist theory, implying that they are valuable tools. In another study by Pee et al. (2007), it was found that a computer game as part of the Year 8 Geography curriculum proved to be valuable as a supplementary learning tool for teaching and learning purposes in addressing global warming issues. It is obvious that the findings of this study is limited to one hundred eighty nine science teacher students, so would be useful to repeat the study with groups in different levels and programs to ensure the validity of the results.

\section{References}

Ağgül, Y. F., \& Yalçın, M. (2015). Turkish Primary Science Teacher Candidates’ Understandings of some environmental problems. 1st International Turkic World Conference on Chemical Sciences and Technologies, 27 October and 01 November 2015 in Bosnia and Herzegovina (Sarajevo).

Akın, S. (2008). Teaching environmental problems arising from motor vehicles, Bushfire, depletion of ozone layer with problem baed learning method. Unpublished Master Thesis. Ataturk University. Institute of Pure and Applied Sciences Erzurum. Turkey

Andersson, B., \& Wallin, A. (2000). Students' Understanding of Greenhouse Effect, The Societal Consequences of Reducing $\mathrm{CO}_{2}$ Emissions and The Problem of Ozone Layer Depletion. Journal of Research in Science Teaching 37(10), 1096-1111. https://doi.org/10.1002/1098-2736(200012)37:10<1096::AID-TEA4>3.0.CO;2-8

Arsal, Z. (2010). Primary teacher candidates' misconceptions of greenhouse effect. Primary education Online, 9(1), 229-240. http://ilkogretim-online.org.tr. Accessed March 2010

Aydın, F. (2010). Secondary school students' perceptions towards global warming: A phenomenographic analysis. Scientific Research and Essays, 5(12), 1566-1570.

Bahar, M. (2000). Undergraduates' previous knowledge levels of environmental education issues and the misconceptions. V. International symposium of ecology and environmental problems. (Main theme: environmental education) The Scientific and Technological Research Council of Turkey, Ankara. Turkey.

Bahar, M., \& Aydın, F. (2002). Primary teacher candidates' level of understanding of greenhouse gases and global warming and the misconceptions. V. National Conference of Science and Mathematics Teaching. Middle East Technical University, Ankara.

Bahar, M., Bag, H., \& Bozkurt, O. (2008). Pre-Service Science Teachers' Understandings of an Environmental Issue: Ozone Layer Depletion. Ekoloji, 18(69), 51-58. https://doi.org/10.5053/ekoloji.2008.697

Bockis, O’M., Veziroglu, T. N., \& Smith, D. L. (2002). Promising energy: hydrogen of sun. Translated by F. Noyan, Kaynak publications. Istanbul, Turkey. 
Boyes, E., \& Stanisstreet, M. (1997). Children's models of understanding of two major global environmental issues (ozone layer and greenhouse effect). Research in Science and Technological Education, 15(1), 19-28. https://doi.org/10.1080/0263514970150102

Boyes, E., \& Stanisstreet, M., (1993). The "greenhouse effect": Children's perceptions of causes, consequences and cures, International Journal of Science Education, 15(5), 531-552. https://doi.org/10.1080/0950069930150507

Boyes, E., Chambers, M., \& Stanisstreet, M. (1995) Trainee primary teachers' ideas about the ozone layer, Environmental Education Research, 1(2), 133-145. https://doi.org/10.1080/1350462950010201

Boyes, E., Stanisstreet, M., \& Papantoniou, V. S. (1999). The ideas of Greek high school students about the "Ozone Layer." Science Education, 83, 724-737. https://doi.org/10.1002/(SICI)1098-237X(199911)83:6<724::AID-SCE5>3.0.CO;2-P

Bozdogan, A. E. (2011). The Effects of Instruction with Visual Materials on the Development of Preservice Elementary Teachers' Knowledge and Attıtude towards Global Warmıng. Turkish Online Journal of Educational Technology, 10(2), 218-233.

Bozdoğan, A. E., \& Yanar, O. (2010). Primary teacher candidates' opinions of what is effects of global warming in next century. Black see journal of science, 1(1), 48-60.

Bozdogan, A. E., Karsl1, F., \& Sahin, C. (2011). A study on the prospective teachers' knowledge, teaching methods and attitudes towards global warming with respect to different variables. Energy Education Science and Technology Part B-Social and Educational Studies, 3(3), 315-330.

Bozkurt, O., \& Aydogdu, M. (2004). Primary 6, 7, and 8 grades' ${ }^{6}$ misconceptions of ozone layer and its function and how to construct them. Journal of Kastamonu Education Faculty, 12(2), 369-376.

Bozkurt, O., \& Cansungu, K. Ö. (2002). Elementary school students' misunderstandings of greenhouse effect at environmental education. Hacettepe University, Journal of Education Faculty, 23, 67-73.

Bozkurt, O., \& Kaya, O. N. (2008). Teaching about ozone layer depletion in Turkey: pedagogical content knowledge of science teachers. Public Understanding of Science, 17(2), 261-276. https://doi.org/10.1177/0963662506071787

Cakir, M., Irez, S., \& Dogan, O. K. (2010). Understandings of current environmental issues: Turkish case study in six teacher education colleges. Educational Studies, 36(1), 21-33. https://doi.org/10.1080/03055690903148522

Celikler, D., \& Kara, F. (2011). Determining the misconceptions of pre-service chemistry and biology teachers about the greenhouse effect. Procedia Social and Behavioral Sciences, (15), 2463-2470. https://doi.org/10.1016/j.sbspro.2011.04.129

Cepel, N. (2008). Ecological problems and their solutions ( $3^{\text {rd }}$ ) Ankara: TUBITAK Popular Books Series.

Cepel, N., \& Ergün, C. (2007). Evidences of global warming. Indigo Journal, 26.

Cinar, M. (2003). Sustainable development and environment. Unpublished Master Thesis Yıldız Technical University, Institute of Social Sciences. Istanbul. Turkey.

Cordero, E. C. (2000). Misconceptions in Australian Students' Understanding of Ozone Depletion, Melbourne Studies in Education, 41, 85-97. https://doi.org/10.1080/17508480009556362

Darçın, S. E., \& Darçın, M. (2009). Secondary school students' level of knowledge of environmental problems arising from motor vehicles. Journal of Gazi Education Faculty, 29(2), 485-512.

Darçın, S. E., Bozkurt, O., Hamalosmanoglu, M., \& Kose, S. (2006). Misconceptions about greenhouse effect. International Journal of Environmental and Science Education, 1(2), 104-115.

Daskolia, M., Flogaitis, E., \& Papageorgiou, E. (2006). Kindergarten teachers'conceptual framework on the ozone layer depletion. Exploring the associative meanings of a global environmental issue. Journal of Science Education and Technology, 15(2), 168-178. https://doi.org/10.1007/s10956-006-9004-8

Demirkaya, H. (2008). Primary teacher candidates' perceptions of global warming and their learning styles: of prospective primary school teachers. Educational Science: Theory and Practice, 8(1), 51-58.

Diffey, B. L. (2000). Sunlight, skin cancer and ozone depletion. In:Hester RE, Harrison RM, eds. Causes and Environmental Implications of Increased W-B Radiation. Issues in Environmental Science and Technology, London: Royal Society of Chemistry, 14, 107-119. https://doi.org/10.1039/9781847550354-00107

Dove, J. (1996). Student teacher understanding of the greenhouse effect, ozone layer depletion and acid rain, Environmental Education Research, 2(1), 89-100. https://doi.org/10.1080/1350462960020108 
Flavin, C. (1990). Slowing Global Warming, American Forests, May-June, 37, 46.

Greenpeace. (1990). Climate Change, A readers guide to the IPCC Reports.

Groves, F. H., \& Pugh, A. F. (1999). Elementary pre-service teacher perceptions of the greenhouse effect. Journal of Science Education and Technology, 8(1), 76-77. https://doi.org/10.1023/A:1009433705790

Groves, F., \& Pugh, A. (2002). Cognitive illusions as hindrances to learning complex environmental issues, Journal of Science Education and Technology, 11(4), 381-390. https://doi.org/10.1023/A:1020694319071

Hansen, P. J. K. (2010). Knowledge about the greenhouse effect and the effects of the ozone layer among norwegian pupils finishing compulsory education in 1989, 1993, and 2005-What Now? International Journal of Science Education, 32(3), 397-419. https://doi.org/10.1080/09500690802600787

Jakobsson, A., Makitalo, A., \& Saljo, R. (2009). Conceptions of Knowledge in Research on Students' Understanding of the Greenhouse Effect: Methodological Positions and Their Consequences for Representations of Knowing. Science Education, 93(6), 978-995. https://doi.org/10.1002/sce.20341

Kahraman, S., Yalcin, M., Ozkan, E., \& Aggul, F. (2008). Primary teacher candidates' awareness of global warming and their level of knowledge. Journal of Gazi Education Faulty, 28(3), 249-263.

Kaya, O. N. (2009). The Nature of Relationships among the Components of Pedagogical Content Knowledge of Preservice Science Teachers: 'Ozone layer depletion' as an exampl. International Journal of Science Education, 31(7), 961-988. https://doi.org/10.1080/09500690801911326

Khalid, T. (2003). Pre-service high school teachers' perceptions of three environmental phenomena, Environmental Education Research, 9(1), 35-50. https://doi.org/10.1080/13504620303466

Koulidis, V., \& Christidou, V. (1999). Models of students' thinking concerning the greenhouse effect and teaching implications. Science Education, 83(5), 559-576. https://doi.org/10.1002/(SICI)1098-237X(199909)83:5<559::AID-SCE4>3.0.CO;2-E

Mcmillan, J. H., \& Schumacher, S. (2004). Research in Education, New York: Longman

Meadows, G., \& Wiesenmayer, R. L. (1999). Identifying and addressing students' alternative conceptions of the causes of global warming: The need for cognitive conflict. Journal of Science Education and Technology, 8(3), $235-239$. https://doi.org/10.1023/A:1009412414470

Oluk, S., \& Ozalp, I. (2007). The teaching of global environmental problems according to the constructivist approach: As a focal point of the problem and the availability of concept cartoons. Educational Sciences: Theory \& Practice, $7(2), 859-896$.

Onat, A., Imal, M., \& Inan, T. A. (2004). Investigation of effect of cooler fluids on ozone layer and alternative cooler fluids. KSU, Science And Engineering Journal, 7(1), 32-38.

Orbay, K., Arzu, C., \&Melek, K. (2009). Teacher candidates' view of global warming. Selçuk University, Journal of Ahmet Keleşoğlu Education Faculty, 27, 85-97.

Ozturk, K. (2002). Global climate changes and its possible impact on Turkey. Journal of Gazi Education Faculty, 22(1), 47-65.

Papadimitriou, V. (2004). Prospective primary teachers' understanding of climate change, greenhouse effect and ozone layer depletion, Journal of Science Education and Technology, 13(2), 299-307. https://doi.org/10.1023/B:JOST.0000031268.72848.6d

Pee, N. C., Blanchfield, P., \& Higgins, C. (2007). Teaching climate change in Year 8!. Editor(s): Remenyi D. Source: Proceedings of The European Conference on Games-Based Learning Pages: 65-70 Published: 2007. Conference Information: European Conference on Games-Based Learning Univ. Paisley, Paisley, Scotland, Oct 25-26, 2007.

Pekel, F. O. (2005). High school students' and trainee science teachers' perceptions of ozone layer depletion, Journal of Baltic Science Education, 1(7), 12-21.

Pekel, F. O., \& Ozay, E. (2005). Turkish High School Students' Perceptions of Ozone Layer Depletion. Applied Environmental Education and Communication, 4(2), 115-123. https://doi.org/10.1080/15330150590934598

Pekel, F. O., Kaya, E., \& Demir, Y. (2007). Comparison of students' understanding of ozone layer with respect to types of high schools they attend. Journal of Kastamonu Education Faculty, 15(1), 169-174.

Rye, J. A., Rubba, P. A., \& Wiesenmayer, R. A. (1997). An Investigation of Middle School Students' Alternative Conceptions about Global Warming, International Journal of Science education. 19(5), 527-551. 
https://doi.org/10.1080/0950069970190503

Selvi, M. (2007). Evaluation of Biology teacher candidates' perceptions of environmental concepts. Unpublished doctoral dissertation. Gazi University, Institute of Educational Sciences, Ankara, Turkey.

Shepardson, D. P, Niyogi, D, Choi, S., \& Charusombat, U. (2009). Seventh Grade Students' Conceptions of Global Warming and Climate Change. Environmental Education Research, 15(5), 549-570. https://doi.org/10.1080/13504620903114592

Spellman, G., Field, K., \& Sinclair, J. (2003). An Investigation into UK Higher Education Students' Knowledge of Global Climatic Change. International Research in Geographical and Environmental Education, 12(1), 6-17. https://doi.org/10.1080/10382040308667509

Summers, M., Kruger, C., Childs, A., \& Mant, J. (2001). Understanding the Science of Environmental Issues: Development of a Subject Knowledge Guide for Primary Teacher Education. International Journal of Science Education, 23(1), 33-53. https://doi.org/10.1080/09500690116990

Topsakal, U. U., \& Kara, S. (2009). Primary teacher candidates' perceptions of ozone layer. Çukurova University, Journal of Education Faculty, 3(37), 13-32.

Yucel, S. A., \& Morgil, I. F. (1998). Investigation of environment phenomenon in higher education. Hacettepe University, Journal of Education Faculty, 14, 84-91.

\section{Copyrights}

Copyright for this article is retained by the author(s), with first publication rights granted to the journal.

This is an open-access article distributed under the terms and conditions of the Creative Commons Attribution license which permits unrestricted use, distribution, and reproduction in any medium, provided the original work is properly cited. 